\title{
The Practicality of Physics Teaching Materials Based on Local Wisdom in the Wetland Environment
}

\author{
Misbah and Mustika Wati \\ Physics Education Program, Faculty of Teacher Training and Education, Universitas Lambung Mangkurat \\ Banjarmasin, Indonesia \\ misbah_pfis@ulm.ac.id
}

\begin{abstract}
The background of this study is that there is no teaching materials that use local wisdom in wetland environment as the problem object in learning. The aim of this study is to describe the practicality of physics teaching materials based on local wisdom in the wetlands. This study is a research and development study and uses the 4D model modified. The practicality of teaching materials is measured by students' response questionnaire for sixty students in two state high schools in the city of Banjarmasin. The result of analysis showed that the practicality of teaching materials have high category in both schools. The result showed that physics teaching material based on local wisdom in the wetland environment is practical to be used in learning at the high school level in a static fluid material.
\end{abstract}

Keywords: physics, teaching materials, local wisdom, wetland environment

\section{INTRODUCTION}

Education is an important aspect for the development of a country. Through education, humans have succeeded in realizing various developments in life. Knowledge and technology develop rapidly due to good education. To achieve better education, the synergy between teachers and students is needed. The teacher is the one who responsible for the whole process of student learning[1]. Therefore, every teacher must have certain competencies. Teacher and Lecturer Law No. 14 year 2005 article 8 states that teachers must have academic qualifications and competencies to realize national education goals. One of the competencies in question is the ability to carry out educational development activities, including being able to utilize technology to develop creative teaching materials. The teacher must be able to arrange teaching materials that are appropriate to the development and needs of students [2].

Optimal learning will be achieved when students are introduced to the local wisdom around them. The local wisdom can be in the form of wealth or customs that are highlighted in the area where the student lives or natural objects that are unique in the student's area [3]. Various characteristics and cultural richness of the community become the basis and at the same time a reference for education [4]. This local wisdom will help students to identify the characteristics of their local area. Beside that, the use of local wisdom can also help students in describing the application of physics learning materials in everyday life. Physics is a science that uses concepts and laws to explain natural phenomena that occur. Studying science in this case physics is not only learning facts, laws, principles, and theories, but also experiencing how the principles and theories are obtained and used in various phenomena around [5]. The physics learning process will be meaningful if the material presented to students is related to the local wisdom of the surrounding environment. In addition, the use of wetlands as a problem object on the topic of static fluids also makes it easier for students to learn and improver student learning outcomes [6].

Banjarmasin area is one of the regions that have quite extensive wetlands. This causes many activities carried out by residents in the wetland environment. This advantage can be utilized to develop teaching materials that can help students visualize learning with local wisdom in the wetland environment by making it the object of the problem [7]. Of the results of observations on teaching materials used at state high schools in Banjarmasin, many schools only use textbooks that are published nationally. The textbooks do not relate learning to the daily lives of students. Beside that, the development of characters is not optimally applied in the textbooks. This reduces the motivation of students to read books because the contents of the book are theoretical, less applicable, and difficult to understand.

One way to overcome problems related to this teaching material is that teachers must develop teaching materials that take a background in local wisdom that is close to students so that it is more applicable. Student learning outcomes can be improved by connecting physics material with local wisdom of the local area [8]. One of the local wisdoms in the wetland environment is lanting houses and floating markets that are associated with fluid material. By so doing, it is intended that students do not get bored in class while learning and students' motivation in learning increases because of students' curiosity about physics through the phenomenon of the lanting house and the floating market. Thus, by making teaching materials based on local wisdom in the wetland environment to train the character of waja sampai kaputing is expected to overcome the problems. This is supported by research result which shows that learning based on local wisdom can increase love for local culture, improve character and student learning outcomes [9-11]. Moreover, a research conducted shows that the use of learning tools based on local wisdom in South Kalimantan can improve student achievement in learning [12-14].

A good teaching material is an easy one to use in the learning process, through practicality testing [15]. One form of practicality testing is to use a practicality questionnaire of 
Table 2 shows that the results of the practicality of

teaching materials aimed at students [16]. Therefore, this study was conducted to describe the practicality of local wisdom-based teaching materials in the wetlands environment of static fluid material.

\section{METHOD}

This research is a research and development, using the 4D model (define, design, develop, disseminate) [17]. After the teaching material developed is tested for its validity and declared valid. Then the next step is to test the practicality of the product being developed. Practicality of teaching materials is seen from the aspects of ease of use, readability, content and time [18]. The instrument used is in the form of a questionnaire [19] and was given to 61 students of class XI at two high schools in Banjarmasin. The research data were obtained from the average results of student questionnaire responses to teaching materials provided which were then matched by the following table [20].

TABLE I. CATEGORIES OF PRACTICALITY OF DEVICES WITH STUDENT RESPONSE QUESTIONNAIRES

\begin{tabular}{|c|c|l|}
\hline No. & Mean Score & \multicolumn{1}{|c|}{ Category } \\
\hline $\boldsymbol{1}$ & $X>3,4$ & Very High \\
\hline $\mathbf{2}$ & $2,8<X \leq 3,4$ & High \\
\hline $\mathbf{3}$ & $2,2<X \leq 2,8$ & Internediate \\
\hline $\mathbf{4}$ & $1,6<X \leq 2,2$ & Low \\
\hline $\mathbf{5}$ & $X \leq 1,6$ & Very Low \\
\hline
\end{tabular}

\section{RESULTS AND DISCUSSION}

Static fluid material has a section containing procedural knowledge, concepts and skills that can be tested with practicum. In this practicum, students are trained on the wasaka character needed during the practicum. The product developed was designed by introducing learning materials through the application of these materials to local wisdom in a wetland environment near student schools. Besides that, the guided inquiry model is used to fulfil practicum activities that exist in each sub material in the static fluid chapter. Teaching materials are prepared in accordance with the revised 2013 Curriculum. Moreover, teaching materials also contain local wisdom. The components of the developed teaching material are in the form of front cover, info, learning material, scientific activities, sample questions, scientific activities, practice questions, reflection and bibliography. In teaching materials, it was also provided worksheets to help students carry out scientific activities to get the concept of each material.

The practicality of the learning instrument was measured by the student response questionnaire. The model that was used in four meetings is guided inquiry. The results of the student response questionnaire are shown in table 2

Table 2 Results of student response questionnaires

\begin{tabular}{|c|c|c|}
\hline Aspect & SMAN X & SMAN Y \\
\hline Ease to use & 2.86 & 2.81 \\
\hline Benefit & 3.07 & 3.07 \\
\hline Time efficiency & 2.93 & 2.98 \\
\hline Mean & 2.95 & 2.96 \\
\hline Category & High & High \\
\hline
\end{tabular}
teaching materials using student questionnaire responses in both schools obtained a high category. This shows that teaching materials developed are practical. The aspect with the highest value is the aspect of benefits. This shows that the teaching material developed greatly helps students in their learning process. This is consistent with the opinion which states that practical teaching materials are teaching materials that can provide ease of use, benefits and also make learning time effective [11], happy and easy to use materials in learning [21,22].

In addition, the calculation result of student responses which is in very practical category indicates that the material developed is able to assist the teacher in carrying out the learning process and is able to assist students in conducting experiments. This is consistent with the results of the study that the existence of the developed teaching materials can facilitate the teacher in carrying out teaching and for students to practice independence and carry out certain tasks [23]. Student activities contained in teaching materials are arranged systematically and use Indonesian that is easily understood. This is in line with development research conducted which states that teaching materials that are arranged systematically can facilitate students in understanding learning through experiments [24].

According to [25] practicality means that the teaching material provided does not complicate anyone who will carry it out. For this reason, instructions for use must be made in a language that is concise, easy to understand and clear. The developed teaching materials do not confuse anyone involved, ranging from students as users of teaching materials, teachers who carry out the learning process, and people who do assessments. This is supported by research which shows that wetland environments around the river oriented teaching material practical to be used by students in achieving learning goals [26]. Through this teaching materials based on local wisdom, it is expected to be practical when used in the learning process [27].

\section{CONCLUSIONS}

Based on the results of product development along with trial results, it can be concluded that teaching materials based on local wisdom in the wetland environment are practical to be used in learning. These results indicate that teaching materials do not complicate students when used.

\section{ACKNOWLEDGMENT}

The author would like to thank Universitas Lambung Mangkurat and the Institute for Research and Community Service of Universitas Lambung Mangkurat because this research was funded through PNBP of Universitas Lambung Mangkurat funds for the 2019 fiscal year. The author also thanks to all parties who helped to carry out this research.

\section{REFERENCES}

[1] S. Rusydie, Tuntutan Menjadi Guru Favorit. Yogyakarta: Diva Press, 2012

[2] A. Prastowo, Panduan Kreatif Membuat Bahan Ajar Inovatif. Yogyakarta: Diva Press, 2015.

[3] U. Utari, I. Degeng, and S. Akbar, "Pembelajaran Tematik Berbasis Kearifan Lokal Di Sekolah Dasar Dalam Menghadapi Masyarakat Ekonomi ASEAN (MEA), " J. Teori Dan Praksis Pembelajaran IPS, pp 39-44, 2016. 
Pokok Bahasan Garis Singgung Lingkaran untuk SMP, "J. Ilm. Pendidik. Citra Bakti, vol.3, no.1, pp 47, 2016.

[16] I. S. Pariska, S. Elniati, and S. Syafriandi, "Pengembangan Lembar Kerja Siswa Matematika Berbasis Masalah, "J. Pendidik. Matematika FMIPA UNP, vol.1, no.1, pp 75-80, 2012.

[17] W. Tiarasari, A. Akmam, \& Z. Kamus, "Validitas dan Praktikalitas Bahan Ajar Mengintegrasikan STL (Sains, Teknologi dan Lingkungan) pada Edmodo Materi Fluida Statik dan Dinamik Kelas XI SMA, "Pillar Of Physics Education, vol.11 no.3, pp 185-192, 2018.

[18] S. Nengsih, T. Septia, and R. Febriana, "Pengembangan Lembar Kegiatan Siswa Berbasis Penemuan Terbimbing pada Materi Peluang untuk Siswa Kelas XI IPA SMA Adabiah 2 Padang, "J. Mosharafa, vol.6, no.2, pp 304, 2017.

[19] K. A. Astiti, "Pengembangan Bahan Ajar Fisika Sma Berbasis Kontekstual Pada Materi Suhu Dan Kalor, "J. Pembelajaran Sains, vol.3, no.1, pp 29-34, 2019.

[20] E. P. Widoyoko, Evaluasi Program Pembelajaran. Yogyakarta: Pustaka Pelajar, 2016

[21] I. N. Yenti, "Kepraktisan Bahan Ajar Berbasise-Learning Untuk Mata Kuliah Kalkulus Peubah Banyak 1 (Kpb 1), "Ta'dib, vol.17, no.1, 1424, 2016.

[22] M. Murniati, and M. Muslim, "Pengembangan Bahan Ajar Mata Kuliah Mekanika Berdasarkan Analisis Kompetensi, "J. Pendidik. Fis. dan Keilmuan (JPFK), Vol.1, No.2, pp 67-73, 2017.

[23] S. Chodijah, A. Fauzi, and R. Ratnawulan, "Pengembangan Perangkat Pembelajaran Fisika Menggunakan Model Guided Inquiry yang Dilengkapi Penilaian Portofolio pada Materi Gerak Melingkar, "J. Penelitian Pembelajaran Fis., vol.1, no.1, 2012.

[24] I. N. Ihsan, M. Arifuddin, and A. Salam, "Pengembangan Perangkat Pembelajaran Berorientasi Lingkungan Sekitar Bantaran Sungai Barito Untuk Melatihkan Keterampilan Proses Sains, "Berk. Ilm. Pendidik. Fis., vol.5, no.3, pp 297-308, 2017.

[25] K. Kusaeri, and S. Suprananto, Pengukuran dan Penilaian Pendidikan. Yogyakarta: Graham Ilmu, 2012.

[26] M. Mukarramah, S. Hartini, and M. Wati, "Pengembangan Lembar Kegiatan Siswa (LKS) dan Media Pembelajaran IPA SMP Berbasis Keterampilan Berpikir Kritis, "Berk. Ilm. Pendidik. Fis., vol.2, no.3, pp 359, 2016.

[27] S. Hartini, M. F. Isnanda, M. Wati, M. Misbah, S. An'nur, and S. Mahtari, "Developing a physics module based on the local wisdom of Hulu Sungai Tengah regency to train the murakata character Developing a physics module based on the local wisdom of Hulu Sungai Tengah regency to train the murakata character," Journal of Physics: Conference Series, Vol. 1088, pp. 012045, 2019. 